\title{
LITERATUR REVIEW:APLIKASI MODEL SOSIAL DALAM PELAYANAN KESEHATAN JIWA PADA IBU HAMIL DENGAN HIV/AIDS
}

\author{
Dian Pitaloka Priasmoro \\ POLTEKKES RS dr.SOEPRAOEN-MALANG
}

\begin{abstract}
ABSTRAK
Tren gangguan kesehatan jiwa saat ini banyak dilatar belakangi oleh penyalahgunaan alkohol, zat adiktif, dan beberapa kondisi penyakit seperti penyakit kronis maupun penyakit infeksi salah satunya adalah HIV/AIDS. Dari sekian banyak penderita sebagian besar adalah pada kelompok ibu hamil dengan resiko penularan pada janin hamper mencapai $91 \%$. Kondisi tersebut akan berdampak kepada kesehatan jiwa wanita, sehingga kelompok ini memerlukan suatu penanganan secara psikososial. Penelitian ini bertujuan untuk mengumpulkan dan menganalisa artikel yang berhubungan dengan aplikasi model pelayanan kesehatan jiwa pada ibu hail dengan HIV/AIDS. Desain yang digunakan adalah literature review, artikel dikumpulkan dengan menggunakan mesin pencari seperti EBSCO, Sciencedirect, dan Proquest .Kriteria artikel yang digunakan adalah yang diterbitkan tahun 2007-2015.Berdasarkan artikel yang dikumpulkan didapatkan hasil bahwa situasi sosial dan menjadi faktor predisposisi gangguan jiwa.Karena kondisi ini akhirnya individu mengalami ketidakmampuan mengkoping stes, ditambah lagi dukungan dari lingkungan sangat sedikit menyebabkan individu mengembangkan koping yang patologis. Peran perawat dalam memberikan terapi menurut model ini adalah pasien harus menyampaikan masalah menggunakan sumber yag ada dimasyarakat melibatkan teman sejawat, atasan,keluarga atau suami istri. Dan berupaya menggali sistem sosial klien seperti suasana dirumah, dikantor, disekolah, dimasyarakat atau tempat kerja.Saran untuk dilakukan riset mendalam khususnya dengan latar belakang budaya di Indonesia yang beragam.
\end{abstract}

Kata Kunci: Aplikasi Model sosial, kesehatan jiwa pada ibu hamil, HIV/AIDS

\begin{abstract}
Trends in mental health disorders is currently a lot of background by alcohol abuse, addictive, and some conditions such as chronic diseases and infectious diseases one of which is HIV / AIDS. Of the many patients are mostly in groups of pregnant women with a risk of transmission to the fetus almost reached $91 \%$. These conditions will affect the mental health of women, so that this group requires a psychosocial treatment. This study aims to collect and analyze articles related to the application model of mental health services in hail mothers with HIV / AIDS. The design used is a literature review, articles were collected by using a search engine such as EBSCO, ScienceDirect, and Proquest. The criteria used are articles published in 2007-2015. Based on the collected articles showed that social situations and predispose the mental disorder. Since this condition eventually individual disability mengkoping stes, plus the support of environmental causes very few individuals develop coping pathological. The role of nurses in providing treatment according to this model is that patients have to address the problem of using existing resources in the community yag involve peers, employers, family or husband and wife. And seeks to explore the social system clients like atmosphere at home, at the office, at school, in the community or workplace.Suggestions to do in-depth research, especially with the background of diverse cultures in Indonesia.
\end{abstract}

Keyword: Application Model of social, mental health in pregnant women, HIV / AIDS

Jurnal Ilmu Keperawatan, Vol:4, No.1 Mei 2016 ,; Korespondensi : Dian Pitaloka P. Program Studi Keperawatan Poltekkes RS dr. Soepraoen Kesdam V/Brawijaya Malang. Jl. SodancoSupriadi No.22 Malang 65147.Telp (0341) 351275,Fax.(0341) 351310 E-mail: priasmoro.pitaloka@gmail.com/ 


\section{PENDAHULUAN}

Secara umum gangguan kesehatan jiwa dilatarbelakangi oleh penyalahgunaan alkohol, zat adiktif, dan beberapa kondisi penyakit seperti penyakit kronis maupun penyakit infeksi. Salah satunya adalah HIV/AIDS. HIV adalah retro virus yang memiliki hubungan dengan virus leukemia sel-T manusia dan retrovirus yang menginfeksi hewan, termasuk primate nonmanusia.Telah teridentifikasi setidaknya dua tipe HIV, yaitu HIV-1 dan HIV-2.HIV-1 merupakan agen kausatif sebagian besar penyakit terkait HIV; namun, HIV-2 tampaknya menyebabkan jumlah infeksi yang terus meningkat di Afrika.HIV terdapat dalam darah semen. Skret serviks dan vagina, dan dalam jumlah yang lebih sedikit, pada saliva, air mata, ASI, dan likuor serebrospinal dari mereka yang terinfeksi HIV (Kaplan\&Saddock,2014).

Infeksi HIV telah tersebar hampir merata diseluruh dunia yang menyebabkan permasalahan masyarakat khususnya masalah kesehatan di negara berkembang. Indonesia adalah negara dengan epidemi rendah HIVAIDS pada masyarakat umum, tapi terkonsentrasi pada populasi tertentu yang mempunyai faktor risiko penularan, seperti masyarakat yang mempunyai perilaku seks berisiko tidak aman dan masyarakat penyalahguna Napza suntik (Penasun) (Kemenkes RI,2011).
Jumlah kasus AIDS yang dilaporkan secara kumulatif sampai September 2011 adalah 28.041. Dari 28.041 kasus AIDS tersebut, proporsi kumulatif kasus AIDS tertinggi adalah pada kelompok umur 20-29 tahun (45,9\%), diikuti kelompok umur 30-39 tahun $(31,1 \%)$ dan kelompok umur 40-49 tahun (9,9\%). Dari jumlah proporsi tersebut tertinggi diketahui pada kelompok umur 20-29 tahun, dan diantaranya adalah ibu hamil.(Kemenkes RI,2011). Pada tahun 2014 dilaporkan oleh The Joint United Nations Programme on HIV/AIDS (UNAIDS) di Negara bagian Afirka mencapai $87 \%$ dari 1,5 juta wanita hamil hidup dengan HIV/AIDS dan 91\% anak yang dilahirkan hidup dengan HIV/AIDS (Ezeanolue et al,2015). Tentunya kondisi tersebut akan berdampak pada kesehatan jiwa wanita. Kesehatan jiwa wanita sangat mempengaruhi kesehatan wanita. Pada usia produktif gangguan kesehatan jiwa wanita sering berhubungan dengan perannya sebagai ibu, istri, dan pekerja. Proses berduka, kemurungan, psikosa paska melahirkan, bunuh diri merupakan reaksi negatif dari gangguan terhadap kesehatan jiwa (Hamid,2011). Brazil's AIDS Treatment melaporkan penanganannya ibu hamil dengan HIV/AIDS adalah penggunaan anti retroviral $(A R V)$, akses gratis pengobatan HIV sampai tingkat pelayanan tertinggi kepada ibu hamil dan anak yang dilahirkannya (Manenti et al,2011). 
Sedangkan di Indonesia Kementrian Kesehatan juga melakukan upaya pencegahan penularan dan penanganan ibu hamil positif yang meliputi 4 kegiatan pokok, antara lain:mencegah penularan HIV pada wanita subur, mencegah kehamilan yang tidak diinginkan pada wanita dengan HIV, mencegah penularan penularan HIV dari ibu kepada bayinya, serta pemberian dukungan psikososial bagi ibu dengan HIV dan keluarganya (Kemenkes RI,2011).

Berbagai model konseptual keperawatan jiwa dikembangakan dan diterapkan kepada pasien, salah satunya model sosial dengan tujuan memberikan pelayanan holistik.Berdasarkan latar belakang di atas maka penulis tertarik membahas "Pelayanan kesehatan jiwa pada wanita:aplikasi model sosial dalam pelayanan kesehatan jiwa pada ibu hamil dengan HIVAIDS".

\section{METODE}

Metode yang digunakan dalam penulisan artikel ini adalah literature review. Yaitu sebuah pencarian literatur baik internasional maupun nasional yang dilakukan dengan menggunakan database EBSCO, ScienceDirect, dan Proquest. Pada tahap awal pencarian artikel jurnal diperoleh 21.939 artikel dari 2007 sampai 2015 menggunakan kata kunci "pelayanan kesehatan jiwa pada ibu hamil", "HIV/AIDS pada ibu hamil", dan"model social dalam keperawatan jiwa" yang diidentifikasi yang belum dieksplorasi relevansi dengan artikel untuk dikompilasi. Dari jumlah tersebut hanya sekitar 53 artikel yang dianggap relevan.Dari jumlah artikel karena tidak ada 10 artikel yang memiliki kriteria penuh, 8 artikel yang berkualitas menengah, dan dua artikel yang berkualitas rendah.

\section{HASIL}

Berdasarkan hasil artikel yang dikumpulkan dan analisa penulis didapatkan bahwa situasi sosial dan menjadi faktor predisposisi klien mengalami gangguan jiwa, seperti kejadian kemiskinan, masalah keluarga dan pendidikan yang rendah.Karena kondisi ini akhirnya individu mengalami ketidakmampuan mengkoping stes, ditambah lagi dukungan dari lingkungan sangat sedikit.Individu mengembangkan koping yang patologis.Krisis juga bisa menyebabkan klien mengalami perubahan perilaku.Koping yang selama ini dipakai dan dukungan dari lingkungan tidak dapat dipakai lagi sehingga klien mengalami penyimpangan perilaku. Stressor dari lingkungan diperparah oleh hubungan sosial seperti keluarga yang tidak memberikan dukungan, suami yang tidak bertanggung jawab, anak yang nakal, tetangga yang buruk, atau teman sebaya yang jahat akan memunculkan berbagai stressor dan membangkitkan kecemasan. Prinsip proses 
terapi yang penting dalam konsep model social ini adalah Environment Manipulation and Social Support (pentingnya modifikasi lingkungan dan adanya dukungan sosial). Sebagai contoh dirumah harus teratur, bersih, harum tidak bising, ventilasi cukup, penataan alat dan perabotan yang teratur. Lingkungan kantor yang asri, bersahabat ada taman, tata lampu yang indah, hubungan kerja yang harmonis, serta hubungan suami istri yang memuaskan.

Peran perawat dalam memberikan terapi menurut model ini adalah pasien harus menyampaikan masalah menggunakan sumber yag ada dimasyarakat melibatkan teman sejawat, atasan,keluarga atau suami istri. Sedangkan terapis berupaya menggali sistem sosial klien seperti suasana dirumah, dikantor, disekolah, dimasyarakat atau tempat kerja (Yosep,2009).

\section{PEMBAHASAN}

Wanita biasanya memiliki pengalaman dan hasil yang berbeda tentang gangguan jiwa dibandingkan laki-laki. Meskipun masih belun dapat dipastikan apakah gender dalam perkembangan saat ini untuk gangguan jiwa namun untuk wanita dengan scizofrenia, depresi, gangguan kecemasan, agoraphobia, panik, dan post traumatic disorder memiliki kemungkinan hasil perawatan yang lebih baik Sehingga pelayanan kesehatan jiwa pada wanita pada satu dekade ini menjadi fokus dan kajian tersendiri (Kulkarni,2007).

Gangguan kesehatan jiwa yang umum meliputi depresi dan gangguan kecemasan. Di Amerika serikat, prevalensi gangguan kesehatan jiwa yang umum terjadi saat kehamilan telah diprediksi pada kisaran 8\%-13\%. Penyebab gangguan kesehatan jiwa umumnya disebabkan karena posisi pada kehidupan sosial yang tidak berharga, yang ditunjukkan dengan rendahnya tingkat pendidikan, pendapatan yang rendah, dan kehilangan atau tidak adanya dukungan sosial.Terlebih lagi gangguan ini dapat disebabkan karena adanya faktor resiko yang terjadi selama kehamilan atau kehamilan yang beresiko.Seperti gangguan penyakit penyerta saat hamil, HIV/AIDS, prematur ataupun berat bayi saat lahir rendah. Kesemuanya itu akan menyebabkan konsekuensi negatif saat post partum terutama kepada kesehatan psikologis ibu, perilaku perkembangan anak, dan perkembangan saraf (Ibanez,Blondel,et al 2015).

Hampir $30 \%$ wanita hamil dengan riwayat stress, depresi, atau kecemasan menunjukkan masalah kesehatan jiwa di masa mendatang. Di negara berkembang kebanyakan terjadinya gangguan selama kehamilan dan persalinan bahkan dapat menyebabkan kematian setelah periode perinatal.Lebih jauh lagi dua dekade belakangan hasil penelitian menunjukkan bahwa kesehatan jiwa pada kehamilan yang 
buruk berhubungan dengan kelahiran dan perkembangan anak yang selalu bermusuhan (Kingston,Austin,et al 2015).

Gangguan kesehatan jiwa pada wanita hamil dengan HIV/AIDS sering dihubungkan dengan adanya stigma lingkungan terkait penderita penyakit HIV, dimana penyakit ini identik dengan multi sexual partner, wanita perokok atau riwayat konsumsi alkohol maupun penyalahgunaan zat.Pengucilan sosial atau isolasi sosial terhadap penderita sering menyertai kondisi ini(Manenti, 2011).

Hal ini serupa dengan teori sosial yang disampaikan Szass dalam Kaplan\&Saddock, 2014 yang menyatakan bahwa situasi sosial dapat menjadi faktor predisposisi dari gangguan jiwa.Berdasarkan pendekatan model sosial ini kondisi sosial besar pengaruhnya terhadap penyimpangan perilaku. Szass juga berpendapat bahwa lingkungan sosial dapat menjadi tidak menyenangkan denagn memberikan suatu label pada individu. Individu yang diberikan label tersebut biasanya tidak mampu menolak dan menyesuaikan diri dengan norma sosial dan tingkah laku mereka biasanya akan cenderung mengisolasi diri.

Dimensi kesehatan jiwa ini hanya sedikit yang mengetahui dan memahami merupakan bagian dari pelayanan kesehatan profesional. Terlebih lagi kesehatan jiwa ini merupakan aspek penting karena mencerminkan kognitif dan emosional seseorang dalam siklus kehidupannya. Dimensi inilah yang pada perkembangannya menjadi fokus kebijakan pelayanan kesehatan Internasional terutama bagi wanita misalnya di Kanada dan Amerika Serikat. Pelayanan kesehatan promotif menjadi penekanan utama pelayanan dibandingkan dengan upaya pengobatan penyakit. Kesejahteraan individu merupakan hal yang sifatnya subyektif dan disana terdapat beberapa ciri pengukuran diri (Ibanez,Blondel,Prunet et al 2015).

Umumnya beberapa tema digabungkan dan diperoleh hasil yang merupakan kombinasi beberapa kunci mendasar dan mengembangkan berbagai rekomendasi untuk meningkatkan kesehatan jiwa dan menyediakan pelayanan HIV yang lengkap(Duffy et al,2015). Pelayanan prenatal terdiri keikutsertaan dalam pencatatan kehamilan setiap trimester, khususnya awal dan sebelum trimester akhir, jumlah kunjungan selama prenatal( di Perancis ditetapkan 7 kali),jumlah USG (idealnya 3kali) selama kehamilan untuk memantau perkembangan janin. Serta keaktifan kehadiran dalam kelas prenatal utamanya pada ibu yang baru pertama hamil dan yang sudah berkali-kali hamil.Kelas prenatal ditujukan untuk pemberian terapi psikososial. Dimana klien akan dibantu menemukan sumber-sumber dukungan dari lingkungan (Ibanez,Blondel,et al 2015).

Sedangkan menurut Duffy et al, 2015 
pelayanan kesehatan jiwa dan HIV yang terintegrasi terdiri dari 3 tahap, tahap pertama merupakan tahap screening kesehatan jiwa, perawat melakukan identifikasi terjadinya depresi atau ansietas. Ada beberapa alat ukur yang digunakan misalnya SSQ(Shona Symptom Questionare) yang dapat mengetahui gangguan misalnya ide tentang bunuh diri, penyalahgunaan obat-obat. Tahap kedua merupakan tahap intervensi terapeutik, dari data yang terkumpul pada tahap pertama, klien menerima intervensi terapeutik untuk kesehatan jiwa yang positif. Beberapa terapi kelompok diterapkan seperti Focus Group Discussion untuk menggali informasi khusus dalam merencanakan intervensi terapeutik terintegrasi. Perawat melaporkan klien lebih percaya diri dan tetap memiliki harapan dengan adanya ketersediaan konseling, serta memahamkan klien tentang "bagaimana hidup setelah terdiagnosis HIV". Termasuk memberikan pemahaman kepada anggota keluarga dan teman-teman klien bahwa konseling serta dukungan menjadi strategi yang sangat berguna.(Duffy, 2015). Dalm intervensi ini perawat dapat menerapkan berbagai konseptual model keperawatan jiwa salah satunya 'model sosial'. Dijelaskan tentang penerpan model ini oleh beberapa ahli.

Menurut Kulkarni, 2007 hubungan terapeutik antara perawat dan klien dalam hal ini berperan sangat penting dalam bagian penyembuhan klien secara menyeluruh. Intervensi secara khusus pada wanita sebagai seorang ibu difokuskan pada kebutuhan khusus wanita. Sehingga wanita yang telah menjalani pengobatan dan pemulihan emosional dapat kembali bekerja maupun menjalankan perannya sebagai ibu.

Sedangkan menurut Purwanto (2015) proses terapeutik klien dibantu untuk menghadapi sistem sosialnya dengan menggunakan pendekatan primer, krisis intervensi,manipulasi lingkungan dan sistem pendukung sosial, keluarga dan masyarakat yang titik pusatnya adalah kesehatan jiwa masyarakat. Peran klien dan terapis aktif menyampaikan masalahnya dan bekerja sama untuk memperoleh resolusi. Terapis menggali atau mengeksplorasi sistem sosial klien dan membantu pasien menggali sistem yang sesuai dan menciptakan sumber baru. Sebagai hasil akhir pada tahap intervensi terapeutik ini menurut Duffy et al (2015) adalah adanya dukungan dan keterlibatan anggota keluarga maupun teman-teman klien dalam proses konseling. Keterlibatan atau dukungan sekitar dan laki-laki sebagai pasangannya menunjukkan menjadi faktor yang krusial pada wanita dalam menerima kehamilannya yang telah terdeteksi HIV/AIDS(Ezeanolue,2015)

Tahap ketiga atau tahap penerimaan adalah tahap dimana perawat menginisiasi dan memfasilitasi klien berdasarkan penerimaan klien terhadap diri dan kondisinya.Penerimaan 
ini sering terjadi secara internal dari dalam diri klien. Sedangkan secara eksternal dapat terjadi karena konseling, perawat, penyedia layanan kesehatan seperti rumah sakit maupun secara pendekatan agama

Sehingga secara umum proses kunci yang perlu diperhatikan dalam proses tersebut adalah adanya latihan dan supervisi dalam pelaksanaan kesehatan jiwa oleh tenaga kesehatan, hambatan dalam penyediaan dukungan pelayanan psikososial untuk menanggapi klien memerlukan dukungan dari level masyarakat, serta adanya kebijakan yang menerima dan berorientasi terhadap pelayanan klien HIV yang terintegrasi(Duffy, et al 2015).

\section{KESIMPULAN}

Kesehatan jiwa merupakan aspek penting dalam indikator kesejahteraan wanita. Utamanya pada wanita hamil, berbagai macam penyulit dan kondisi fisik sebagai penyerta dalam kehamilan akan menyebabkan stressor

\section{DAFTAR PUSTAKA}

Duffy, Malia et al. (2015). Integrating jiwa health and HIV Services in Zimbabwean communities: anurse and communityled approach to reach the most vulnerable.Journal of the association of nurse in AIDS care, 1-13. tersendiri bagi wanita. Ditambah lagi stressor lingkungan disekitar individu.Untuk itu penenganan yang holistik meliputi penangan fisik dan jiwa perlu dilakukan oleh semua pihak.Pemberian anti retroviral (ARV) serta pemberian dukungan psikososial sangat penting dilakukan. Perawat dalam hubungannnya dengan klien perlu menjalin kerja sama dan tentunya klien berperan aktif dalam mengungkapkan masalahnya dalam rangka menyusun intervensi yang tepat.

Model sosial merupakan salah satu contoh model konseptual khususnya dikeperawatan jiwa yang dapat diterapkan kepada pasien. Fokus model ini adalah focus penanganan khususnya melalui lingkungan sosial yang dapat berpengaruh terhadap individu dan pengalaman hidupnya.

\section{SARAN}

Perlu dilakukan penelitian lebih lanjut dengan sampel ibu hamil dengan HIV/AIDS di Indonesia terutama dengan latar belakang sosial budaya Indonesia yang beraneka ragam.

Ezeanolue, Echezona et al. (2015). Effect of a congregation-based intervention on uptake of HIV testing and linkage to care in pregnant women in Nigeria(Baby shower):a cluster randomised trial. Tha lancet journal, 3, 692-700. 
Hamid, Achir Yani S. (2011).Kesehatan jiwa wanita usia produktif: suatu kajian masalah.

Ibanez,G.Blondel,B et al(2015). Prevalence and characteristics of women reporting poor mental health during pregnancy:finding from the 2010 French National Perinatal Survey.J revue d'epidemiologic atde sante publique.63.85-95

Kulkarni, Jayashri.(2007).Women's mental health.Journal pshychiatric,6(9).377-380

Manenti, Sandra Aparccida et al. (2011). Epidemiologic and clinical characteristic of pregnant women living with HIV/AIDS in a region of Southern Brazil where the sub type C of HIV-1 infection
predominates.Braz J infect Dis, 15(4), 359-355.

O'Brien, Patricia, Kennedy, Winifred Z, \& Ballard, Karen A. (2013).Keperawatan kesehatan jiwa psikiatrik. Jakarta: EGC.

Purwanto, Teguh. (2015). Buku ajar keperawatan jiwa. Yogyakarta: Pustaka Pelajar.

Saddock, Benjamin J. (2014). Kaplan\&Saddock:buku ajar psikiatri klinis. Jakarta: EGC.

Sedyaningsih, Endang Rahayu dkk.(2011). Menuju masyarakat sehat yang mandiri dan berkeadilan. Jakarta: Kemenkes RI.

Yosep, Iyus. (2009). Keperawatan Jiwa. Bandung: PT Refika Aditama. 